This item was submitted to Loughborough's Research Repository by the author.

Items in Figshare are protected by copyright, with all rights reserved, unless otherwise indicated.

\title{
Framing cross-cultural ethical practice in adapt[ive] physical activity
}

PLEASE CITE THE PUBLISHED VERSION

http://dx.doi.org/10.1080/00336297.2015.1117501

\section{PUBLISHER}

Taylor and Francis / @ National Association for Kinesiology in Higher Education (NAKHE)

\section{VERSION}

AM (Accepted Manuscript)

\section{PUBLISHER STATEMENT}

This work is made available according to the conditions of the Creative Commons Attribution-NonCommercialNoDerivatives 4.0 International (CC BY-NC-ND 4.0) licence. Full details of this licence are available at: https://creativecommons.org/licenses/by-nc-nd/4.0/

\section{LICENCE}

CC BY-NC-ND 4.0

\section{REPOSITORY RECORD}

Goodwin, Donna, and David Howe. 2019. "Framing Cross-cultural Ethical Practice in Adapt[ive] Physical Activity”. figshare. https://hdl.handle.net/2134/20875. 
Abstract

2 Academics and practitioners are often at a loss when it comes to understanding the ethical socio-

3 political and cultural contexts that invades the world of adapted physical activity (APA). Ethical

4 practice is situated in the local and the specific. In this paper we highlight that both academics

5 and practitioners need to be ever mindful that the cultures surrounding the education, sport and

6 rehabilitation components of APA are distinctive environments that vary across the globe.

7 Because of the cultural diversity surround APA, we set out an embryonic framework for

8 ethically thinking about practice in our field. Ultimately we hope that this framework will go

9 some way to illuminate questions of situated ethical importance that are becoming increasing

10 conundrums within APA.

11 Keywords: professional practice, disability, ethical framework, adapted physical activity 
Framing Cross-cultural Ethical Practice in Adapt[ive] Physical Activity

Reflecting on our thinking in adapted physical activity (APA) would be incomplete

without consideration of the internal and external moral compasses that guide our professional

practice. ${ }_{-}^{1}$ Diverse perspectives can be achieved, in part, by bringing an ethical lens to the premises, actions and rituals of APA. As “practical ethics is not the type of inquiry to be advanced by the lone thinker or narrow scholar,” (Higgins, 2010, p. 255) we invite others to engage with our ethical thinking in APA.

This paper explores the contribution that human science ${ }^{2}$ can make to our thinking about the ethical professional practice and the role of universities in preparing professionals for increasingly complex workplaces. Adapted physical activity is a field of passionate and dedicated professionals and researchers and for this reason; we feel that open dialogue about difficult issues is possible. Kagan (2009) reminds us that the function of humanistic scholarship is "to provide divergent perspectives on the human condition...by inviting students to brood more deeply on the causes of the ethical void in modern society” (p. 231). Whereas humanist recognize uncertainty as a prevalent human emotion, those in the natural or social sciences may be less comfortable with understanding feelings in themselves and others, inconsistencies in their beliefs, or choosing behaviour among several possibilities (Kagan, 2009). Ethics is a language of ambiguity and one may be more or less comfortable with the uncertainty inherent in questions of right and wrong and goodness and badness. ${ }^{3}$ Its vocabulary may take time to be understood and applied within the cultures of APA research in the natural science, social science, and the humanities (Kagan, 2009).

Thinking ethically may not garner high prestige from colleagues or university leadership who adhere to science traditions other than human science as it does not require large grant 
47 support, or reap academic funding notoriety to engage deeply in reflective and reflexive ethical

48 thought. It relies on philosophy, the semantics of language and texts, and pragmatic

49 consequences (knowing rather than doing) that may not be quickly realized (Kagan, 2009).

50 Nonetheless, thinking ethically using the tools of humanistic science brings the extraordinary

51 particularity of people’s lives and events to light (Silva \&Howe, 2012). It creates a window for

52 viewing the culture premises, hierarchical power structures, decision making configurations, and

53 moral dilemmas embedded in the how, why, what, and where of APA that can have profound

54 impacts on dignity ${ }^{4}$ (Goodwin, Johnston, \& Causgrove Dunn, 2014).

55 Ethical judgements are inherent in the complex environments in which professional

56 practice and field research occurs. Further, ethical judgements are mediated by (situatedness)

57 the social-political context in which they transpire (e.g., schools, disability sport, community

58 recreation centres, fitness facilities; Simons \& Usher, 2000a). Ethical decisions are taken against

59 a backdrop of personal beliefs, organizational complexities, and potentially conflicting

60 expectations. We all have a role to play in contributing to a deeper understanding of the human

61 condition because as professionals we work with people who are often disadvantaged by the very

62 values we may hold (Goodwin, 2008; Goodwin et al., 2014; Peers, 2012a, 2012b).

63 As the title of this paper illuminates, we feel 'Adaptive Physical Activity' (over adapted physical

64 activity) is more in line with a reflexive ethical stance in which practitioners should continually

65 engage. The use of a different suffix is significant. The term adapted implies that adaptation has

66 occurred. On the other had adaptive implies that practitioners are 'able to do or doing ${ }^{5}$ which we

67 believe is paramount for a reflexive ethical position to be developed. The gains we have made in

68 our field over the past decades have been due to the placement of the individual in the middle of

69 our understanding (e.g., individualization of our instruction). We have done this by modifying, 
70 adapting, and accommodating to "meet unique needs and achieve desired outcomes" (Sherrill,

71 2004, p.7). The danger that is becoming apparent with the "top-down instructional (or

72 intervention) model based on adaptation theory" (Sherrill, 2004, p. 84) or individual in the

73 middle approach is that focus is upon changing the individual, with little impetus to change the

74 social and cultural influences that gave rise to the creation of the individual (e.g., assessment,

75 prescription, intervention, evaluation, classification, labeling, monitoring). By placing the

76 individual with the marginalizing forces (including professional beliefs, attitudes, and practices),

77 the focus shifts to changing that which excludes, devalues, and Others - rather than changing the

78 individual. adaptive" (p. 9). Adaptive physical activity then, we propose is what we do to ourselves

81 [behaviours] that fosters flourishing in others (Seligman, 2012). As professionals and scholars,

82 our behaviour is adaptive. The work (project) of adaptive physical activity (professionals) is to

83 reflect on our ableism, disablism, perpetuation of the normate as the desired state of being,

84 ethical responsiveness, and desire for relationship building. We have been influenced by scholars

85 working in disability studies in our suggestion that it the professional practitioner who should be

86 adaptive, and not the person experiencing disability who should adapt (e.g., Titchkosky, 2003,

87 2011; Shakespeare, 2006; Withers, 2012). An interdisciplinary approach to adaptive physical

88 activity may deepen our understanding of our belief systems and ethical knowing.

89 In other words, our field of endeavour is not static, but alive and constantly changing. We urge

90 readers to engage in this debate and consider the benefits of explicitly articulating our field as a

91 dynamic one.

92 Reflexivity in APA: Moral Discomfort 
Ethical judgements are part of professional life. We contend that there are times (pre-

94 service and in-service) when deep internal reflective self-evaluation that involves debating,

95 arguing, and bargaining with ourselves is a professional imperative (DePauw, 2009). Inherent in

96 applied ethics (ethics in action as well as thought) are the concepts of external and internal

97 integrity. “'Being true to one’s self and one’s most cherished values (internal integrity) is

98 integral to a 'moral career'” (Simons \& Usher, 2000b, p. 3). External integrity involves

99 relationships with others as compromises in practice are made between people, social groups,

100 and organizations and debates, negotiations, and evaluations of policies and practices occur.

101 "Maintaining moral careers involves regular changes in how persons view themselves and their

102 criteria for judging themselves and others” (Glen, 2000, p. 13). The moral complexities of APA

103 settings are further complicated by external practical professional constraints such as time,

104 staffing, educational backgrounds, energy, or policy.

105 Researchers and teachers in higher education have a moral obligation and social

106 responsibility to incorporate questions of ethical practice and conduct into their teaching and

107 share their own moral discomfort when there is not a clear answer (DePauw, 2009; Goodwin \&

108 Peers, 2012). The apparent disregard for reflexivity in ethical pedagogy in APA may be due, in

109 part, to adherence to a school of thought called virtue ethics. Virtue ethics is based on the

110 premise that good people will make good decisions and as such, it “...appeals to our intuitive

111 sense that one who cares for vulnerable people ought to demonstrate particular personal

112 characteristics” (Oberle \& Raffin Bouchal, 2009, p. 11). Virtues can be learned, so if APA

113 attracts people who believe themselves to be virtuous and are reinforced for their good work

114 (practice) toward those considered to be vulnerable (e.g., persons experiencing disability), the

115 need for reflection on ethical professional practice may seem to become redundant. The very 
116 assumption of virtuous professionals has profound ethical consequences.

117 Virtuous professionals can lead to the creation of two groups of people - the benevolent

118 us, and the vulnerable them. The creation of services for those who are vulnerable, marginalized,

119 and excluded from the activities and benefits of the community, by that very community, created

120 a disability industry that provides jobs and creates profits for those without impairments

121 (Albrecht, 1992). Arguably, few professionals would articulate APA as part of the disability

122 business and yet, some from within still refer to APA as a family thus presupposing a nurturing

123 relationship between professional and 'client.' Unpacking the ethical minefield that surrounds

124 APA may enable us to move the field forward toward mutually respectful and ethical

125 engagement (Bergum \& Dossetor, 2005).

126 Two distinct yet inter-related approaches may move an ethical agenda in APA forward

127 (Goodwin \& Standal, 2012). In a top-down approach, ethical theory as reflected in philosophy

128 and contemporary social theory is applied to issues of ethical concern. In the bottom-up

129 approach, APA practice is informed by empirical knowledge of the participants' perspective on

130 aspects of psycho-social and cultural interactions prevalent in professional practice (e.g., use of

131 'help’ [Goodwin, 2001], 'peer learning’ [Standal \& Jespersen, 2008] or ‘disability simulations’

132 [Leo \& Goodwin, 2013, 2014]). Analysis of evidence gathered from the bottom-up perspective,

133 may illuminate the ethic being applied to APA professional practice (Goodwin \& Rossow-

134 Kimball, 2012). Yet to be addressed bottom-up (lived experience) questions of importance to

135 understanding the moral integrity of APA practice include: (a) Are we, and how do we, diminish

136 dignity or resistance to the remove of obstacles to active lifestyles (Malloy \& Zakus, 1995)? (b)

137 How we assess and apply supports to enhance or delimit personal agency (Anderson, 2006;

138 Carnevale, 2004; Rossow-Kimball \& Goodwin, 2009)? and (c) What is the position of lived 
139 disability knowledge (embodied knowledge) in the research process (Austin, Bergum, \&

140 Dossetor, 2003; Wadensten \& Ahlstrom, 2009)?

141 Important top-down questions to illuminate the moral contexts of APA include: (a) What

142 role can ethical theory (e.g., care, principlism, relational ethics) play in our understanding of the

143 knowledge landscape of APA (Austin, 2007)? (b) Do we partake in thoughts and actions that

144 create and perpetuate, or dispel and reject the creation of the Other through expertism and

145 professional entitlement (e.g., engage in discourses of disability objectification, tragedy and

146 catastrophe) (Banja, 2005; Clapton, 2003; MacDonald, 2002), and (c) Do interventions modify

147 and accommodate the person or the social and political context (Sullivan, 2005)? Working

148 through practical predicaments and the pragmatic realities may offer practitioners distinctive

149 good in four areas: “outstanding works or performances to appreciate, a rich moral

150 phenomenology to experience, excellences of character to display and on which to rely, and a

151 biographical genre through which to shape a meaningful life” (Higgins, 2010, p. 250).

\section{The Experience of Disability Ethics}

153 Research approaches that embrace lived experiences provide insights into first person

154 perspectives (Howe, 2009), that although frowned upon by some as mere subjectivism, or at their

155 worst, symbolic violence of outsiders trying to empathize with that which they have played a role

156 in creating, can serve as a critical lens to view the experiences of ability and disability

157 (Anderson, 2006; Jespersen \& McNamee, 2008). The ethical work required of APA

158 professionals involves understanding how ethical issues arise, how they are structured, and how

159 they are managed (Borry, Schotsmans, \& Dierickx, 2005; Updale, 2008).

160 The ascent of humanist research and postmodern challenges to the validity of prediction

161 and group models in the social science contributed to an alternate way of understanding 
162 disability influenced by an implicit ethical ideal. Humanists reminded society of its

163 contradictions, cultural premises, the place of emotion, and the presence of moral dilemmas.

164 Further, postmodernism brought a questioning of unquestioned premises, historically favoured

165 methodological tools, and core concepts (theories) of explanation (Kagan, 2009). Higgins

166 (2010) states that understanding professional practice requires a back and forth shuttle between

167 views from the practice and depictions of the practice from the outside.

168

169

170

171

172

173

174

175

176

177

178

179

180

181

182

183

184

A good starting point, then, is to collect internal descriptions of putative practices.... thick, phenomenological evocations of...settings, goals, episodes, communities, traditions....What such first-person reports offer is an introduction to vocabulary and sensibility of the practice....Without joining the practice, and on the basis of such reports alone, we cannot truly know what it is like to participant in the practice. (Higgins, 2010, p. 255)

Case studies of situated texts can be used to bring new interpretations to participants' life worlds (Prosser, 2000). This interpretation of these narratives is not meant to find the meaning of a text rather it is about creating another text by remaining open to multiple meanings in a process that does not have boundaries, since interpretation is socio-politically and culturally embedded (Usher, 2000).

Ethical understanding of (counter)stories ${ }^{6}$ or stories constructed from the lived experiences of persons with impairments may offer alternative understandings and an appropriate ethical platform from which to engage in crucial discussions (Clapton, 2003).

Hearing (counter)stories is arguably fundamental to our understanding of professional practice in APA so as to bring tact to our instruction (van Manen, 1991). It is a place for the teller and the listener to come together to begin to undermine the dominant story, undoing it and retelling it in 
185 a way that invites new interpretations and conclusions. We contend that more (counter)stories

186 need to be heard in APA. Ethical understanding constructed from the lived experiences of

187 persons with impairments will offer alternative understandings to practice tradition and an ethical

188 platform from which to engage in crucial discussions.

190 deconstruction of the reality seeks to unleash the concealed metaphors within, or theorise and 191 disrupt the ideology that reproduces itself through texts of stories. “Text is any organized 192 network of meaning, a field of contending differential forces whose characteristics is that it is 193 always interpretable, capable of being read and re-read...” (Usher, 2000, p. 168). Post

194 structuralism (deconstructionism) may provide an exemplification of the ethical moment, one 195 that does not involve pre-existing norms and guiding rules, "Deconstruction is an ethics,” not in 196 the sense that ethics is the application of ethical codes, but rather there are ethical moments and 197 the deconstruction of those moments is an expression of ethics (p. 162). Deconstruction

198 becomes an ethics through the assumed responsibility marked by an obligation to listen as a way 199 of showing respect for the Other and being with the Other, not trying to assimilate or incorporate 200 the Other through programming, silencing, or neglecting the Other (Popke, 2003).

\section{Disquieting the Expert}

202 Ken Davies, (1993) in his article: “The Crafting of Good Clients,” states that 203 professionals “...learn about disability by doing courses and reading books. Some of them are 204 given diplomas for doing this....These paper qualifications help them get jobs and make careers 205 out of our needs” (p. 197). Davies, among others, has questioned the ethical motivations of 206 people who work in the disability field (Fitzgerald, 2009, Macbeth, 2010, Shakespeare, 2006).

207 Professionals through their expertise have the power to control and exclude. Some argue that the 
208 process of professionalization creates individuals who, on the basis of knowledge they assume to

209 be objective, believe they are acting in the best interests of others. This suggests that the key

210 activities of “ethical work” are the deconstruction, criticism, and professional beliefs including

211 how we come to know, speak, interact with others (Trussell, 2010). Activities in APA develop

212 into practice and are aligned with four social criteria: (a) they are social in origin (vocabulary

213 and shared understanding), (b) social in execution, (c) based in historical traditions (what it is

214 and what can be achieved), and (d) they are passed along to others (initiation and teaching)

215 (Benner, 2004). In Figure 1, we illustrate the interaction of the four social criteria as a way of

216 looking at professional ethics, not as something that is applied to professional practices: it is

217 something that is fundamentally practical and there may be not right course of action, but rather

218 action that is done admirably with tact and integrity (Higgins, 2010, p. 237). Professional

219 practice in APA is bound by social and cultural influences and the values it holds, for example,

220 the ideology of inclusion is good for society. In spite of having multiple meanings in the field

221 inclusion has become an ethic for the knowledge landscape of APA. Further, professional

222 activities that support inclusion (e.g., individualized support) are acted out in particularistic and

223 contextually specific settings that bring about ends. As practitioners apply their knowledge

224 landscape through action, their practices become normative as they are evaluated and synthesised

225 by individuals (moral traditions). Tension arises however, when the knowledge landscape

226 (moral traditions), normative professional practice (professional life narratives), and outcomes of

227 practice (disability lived experiences) do not lead to flourishing or well-being of the practitioner

228 or the participant (Higgins, 2010). An (upward) reliance on the lived experiences of people with

229 impairments gives rise for reflection on individual, communal, and societal norms thereby

230 providing fabric for questioning what is worth striving for, the potential for innovation in our 
231 doing, and new ideas to refocus and invigorate our thinking.

232 By working alongside fellow practitioners in professional practice, we come to learn

233 about the profession and the dynamic interplay between professional and practical knowledge,

234 in essence the good and the bad of the practice (Clandinin \& Connelly, 1996). Professional

235 knowledge is information of what is right given theory driven or ideological views of practice

236 that is reinforced by policy makers and administrators. The professional knowledge landscape

237 becomes the sacred story that tells us who to 'be' and what to 'do.' Sacred stories can be

238 problematic since they often transform into 'truths' that are ritualised in APA circles - that are

239 rigid, unchallenged and unchanged. As professionals, we need to work tirelessly to avoid this

240 ritualization of sacred stories. The professional knowledge landscape is comprised of a dynamic

241 interaction of professional knowledge that includes codes of conduct learned through theory and

242 formal educational contexts with normative rules, some of which are the product of ritualised

243 sacred stories and ethics of duty that guide our action. Practical knowledge is comprised of

244 stories created by practitioners where they are generally free from scrutiny and live stories of

245 practice - a place of secret story where professional life narratives emerge. Practical knowledge

246 of what is good or bad is learned through practice in a space that is private and integrates

247 personal virtues with relational knowing.

248 If a practitioner is aware of, or anticipates dissension between the sacred story and the 249 secret story, one can live and tell a cover story. Moral discomfort may arise when the domains

250 of ethical life, that is the sacred stories we are told, secret stories we live, and cover story we tell

251 are different. Unpacking stories of sacredness, stories of secrecy, and stories used for 'cover' is

252 an essential part of the ethical work required in APA. 
253 Well-established and intuitively sound "best practice” such as use of peer tutors (Standal \&

254 Jespersen, 2008; Goodwin, 2009), adaptations of rules and equipment (Doubt \& McCall, 2003), and providing choice (Morphy \& Goodwin, 2012), reduce pressures that exclude disabled students (Goodwin, 2009). For example, peer tutoring in inclusive physical education is an effective strategy for providing supplementary assistance socially, physically, and instructionally (Klavina \& Block, 2008). Peer tutoring as it is depicted in much of the APA literature assumes

the tutor will be a student without impairment who 'helps' the student with impairment.

Embedded within this practice are questions of dependency, marginalizing, and Othering of the

student with impairment that are carried by the student well beyond the lesson? Further, what

power, privilege, and authority for the student without impairment do these scenarios create in

her or his eyes and that of fellow classmates? Would the student with impairment ever be

selected to be the tutor? We are not advocating the elimination of peer tutoring. However,

unreflected practices may create what has been termed "special education damage" in the forms

of dependency, perceptions of incompetence, and stigmatization (Allen, 2005, p. 286). Research

into the experiences of those who receive (endure) being the tutee will bring a balanced

perspective to the benefits and dangers of the use of peer tutors (Standal \& Jespersen, 2008).

The ethical work of inclusion involves the critical reflection upon values such as autonomy,

270 integrity, influence, and participation. In full fairness to teachers, we know they also fall victim

271 to ethically questionable practices such as inadequate preparation (Hodge, Ammah, Casebolt,

272 LaMaster, \& Sullivan, 2004), inadequate classroom support (Lienert, Sherrill, \& Myers, 2001),

273 and administrative abandonment (Goodwin, 2009). One must ask whether perceptions of "best

274 practice” have replaced ethical discussions, and whose responsibility it is to re-open this dialogue

275 (Austin, 2007). We are aware of the insecurity that turning back on traditions and long standing 

297 story” (Pellegrino, 2000, p. 644).

\section{Conclusion}

practices creates and the desire to replace the old with something that is new or better. Rather

than shying away from the insecurity induced by internal self-evaluation however, Standal

(2008) celebrates the openness to new understanding that it creates. "Understanding is a

practical-moral activity that is concerned more with engaging with that which is to be

understood, than grasping the content of it” (Standal, 2008, p. 211).

\section{Foundations for an Ethical Community in APA}

A focus on ethics can be framed by empiricism, focusing on empirical description, reconstruction, and analysis of lived experiences reflected in the cultural context of the disability community and the community of professional practice in APA. It can also be guided by normative principles that are themselves ethical in formulation (Skrtic, 1995). Although universal principles (e.g., nonmaleficence, beneficence, autonomy, and justice) (Beauchamp, 1994) can assist in the process of reflecting upon internal integrity, they can be self-limiting if they replace thinking and problematizing the situatedness of the interactive context (Glen, 2000). The two ethical approaches are not to be regarded as successive stages in professional advancement, but as co-existing in ethical practice - offering a way of envisioning and conceptualizing the practice of adapted physical activity (Gadow, 1999). Knowledge of ethical theory and principles facilitates our conceptualization of ethics. Such knowledge alone however, is not sufficient for ethical professional practice. We need both - objective abstract knowledge (e.g., principle of autonomy is liberating) and subjective knowledge (e.g., lived autonomy can be isolating; Bergum \& Dossetor, 2005). “To understand the direction of moral decisions in any person's life; we need as much knowledge as possible of the forces that shape that person's life 
Practice within APA contexts can result in harm, but it also offers practitioners distinctive

300

301

302

303

304

305

306

307

308

309

310

311

312

313

314

315

316

317

318

319

320

321

goods of a least four types: outstanding works or performances to appreciate, a rich moral

phenomenology to experience, excellences of character to display and on which to rely, and the

biographical genre through with to shape a meaningful life (Higgins, 2010). Our aim was not to lecture about all that is bad in adapted physical activity practice, but rather to bring awareness of the need to trouble taken-for-granted professional practices - of both what is right and wrong and good and bad. The subject of our professional practice, disability, is a value-laden, contested and cultural construct.

The cultural politics that surrounds APA facilitates the telling and retelling of sacred stories that can be transformed into rituals and their associated behaviour that profit the disability business and discourage new recruits to the 'family' from being reflexive on our practice. This creates a field that has the potential to stagnate and reproduce itself - because this is considerably easier than the alternative. Secret stories that we tell ourselves need to be removed from our daily practice as do cover stories that hide the institutional practices from the public gaze. What we need to see is a removal of the barrier between sacred and (counter)stories, thus freeing us from the potential of sacred stories becoming ritualized practices. In this way, the field of APA becomes more active - with people with impairments at its heart. Not adapted to the client base in a static and formulaic matter but adaptive to the every changing counter(stories) that need to be our raison d'etre - the place that we begin using both our practical and professional knowledge to facilitate the enhancement of the lives of people with impairments.

This is a starting point, a change in approach, but one we believe is simple enough to make in isolation. We certainly feel we could encourage our students to follow us with a more adaptive approach to physical activity - our own biographies tell us this is the case. Across the 
322 APA field - we are likely to meet structural and agential resistance. How we transform our field

323 ethically is not as simple as leading by example. We depart with several ethical questions:

324 - How can we resolve the criticism that knowledge in APA is primarily generated from a

325 non-disability power base, which perpetuates a colonialist ethic?

326 - In what ways does APA name, classify, divide, mark, delineate, limit and create

327 boundaries? What relational power hierarchies are at play and what are the impacts?

328 - Who are the meaning and sense-makers in storytelling regarding disability experiences

329 and how might that influence interpretation and perpetuation of the Other?

330 - How has the ethic of political correctness (e.g., person first language) misrepresented the

331 socio-political reality of disability? (Peers, Spencer-Cavaliere, \& Eales, 2014)

332 - What is our responsibility toward others and what politics are brought to bear on that

333 responsibility? 


\section{References}

336 Albrecht, G. L. (1992). The disability business: Rehabilitation in America. Newbury Park, CA: Sage.

Allen, J. (2005). Inclusion as an ethical project. In S. Termain (Ed.), Foucault and the government of disability (pp. 281-297). Ann Arbor, MI: University of Michigan Press.

Anderson, (2006). Teaching (with) disability: Pedagogies of lived experience. The Review of Education, Pedagogy, and Cultural Studies, 28, 367-379.

Austin, W. (2007). The ethics of everyday practice. Advances In Nursing Science, 30, 80-88.

343 Austin, W., Bergum, V., \& Dossetor, J. (2003). Relational ethics. In V. Tschudin (Ed.), Approaches to ethics (pp. 45-52). Woburn, MA: Butterworth-Heinemann.

Banja, J. D. (2005). Reflections on the ethical dimensions of outcomes research. Rehabilitation Psychology, 50, 79-86.

Beauchamp, T. L. (1994). The ‘four principles’ approach. In R. Gillon (Ed.), Principles of health care ethics (pp. 3-12). Hoboken, NJ: John Wiley \& Sons.

Benner, P. (1997). A dialogue between virtue ethics and care ethics. In C. D. Thomasma (Ed.). The influence of Edmund D. Pellegrino's philosophy of medicine (pp. 47-61). of American Journal of Critical Care, 13, 346-349. Retrieved from http://ajcc.aacnjournals.org/content/13/4/346.short

355 Bergum, V., \& Dossetor, J. (2005). Relational ethics: The full meaning of respect. Hagerstown, MD: University Publishing Group.

357 Borry, P., Schotsmans, P., \& Dierickx, K. (2005). The birth of the empirical turn in bioethics. 
Bioethics, 19, 49-71.

359 Carnevale, F. (2004). Listening authentically to youthful voices: A conception of the moral agency of children. In J. I. Storch, P. A. Rodney, \& R. C. Starzomski (Eds.), Toward a moral horizon (pp. 396-413). Toronto, ON: Prentice Hall.

362 Clandinin, D. J., \& Connelly, F. M. (1995). Teachers’ professional knowledge landscapes. New York, NY: Teachers College Press.

Clandinin, D. J., \& Connelly, F. M. (1996). Teachers’ professional knowledge landscapes: Teacher stories - stories of teachers - school stories - stories of schools. Educational

Clapton, J. (2003). Tragedy and catastrophe: Contentious discourses of ethics and disability. Researcher, 25, 24-30.

Davies, K. (1993). The crafting of good clients. In J. Swain, V. Finkelstein, S. French, \& M.

DePauw, K (2009). Ethics, professional expectations, and graduate education: Advancing Practice, 14, 19-21.

Fitzgerald, H. (2009). Are you a 'parasite researcher'? Researching with young people. In H.

Fenton, E., \& Mitchell, T. (2002). Growing old with dignity: A concept analysis. Nursing

Doubt, L., \& McCall, M. (2003). A secondary guy: Physically disabled teenagers in secondary 
381 Glen, S. (2000). The dark side of purity or the virtues of double-mindedness? In H. Simons \& R. 382 Usher, Situated ethics in educational research (pp. 12-21). New York, NY: Routledge.

383 Goodwin, D. L. (2001). The meaning of help in PE: Perceptions of students with physical 384 disabilities. Adapted Physical Activity Quarterly, 18, 289-303.

385 Goodwin, D. L. (2008). Self-regulated dependency: Ethical reflections on interdependence and 386 help in adapted physical activity. Sport, Ethics and Philosophy, 2, 172-184.

387 Goodwin, D. L. (2009). The voices of students with disabilities: Are they informing inclusive 388 physical education? In H. Fitzgerald (Ed.), Disability and youth sport (pp. 53-75). London: Routledge.

Goodwin, D. L., Johnston, K., \& Causgrove Dunn, J. (2014). Thinking ethically about inclusive recreation: A narrative of lost dignity. Sport, Ethics and Philosophy, 8, 16-31.

392 Goodwin, D. L., \& Peers, D. (2012). Disability, sport, and inclusion. In S. Dagkas (Ed.), Inclusion and exclusion through youth sport (pp. 186-202). Oxon, UK: Routledge.

394 Goodwin, D. L., \& Rossow-Kimball, B. (2012). Thinking ethically about professional practice in adapted physical activity. Adapted Physical Activity Quarterly, 29, 295-309.

396 Goodwin, D. L., \& Standal, O. (2012). Informing ethical practice in adapted physical activity through research. In C. Boursier (Ed.), Adapted physical activity: Translating theory and evidence into practice (pp. 25-36). Paris, France: The New Review of Adaptation and Schooling (NRAS).

Higgins, C. (2010). Worlds of practice: MacIntryre’s challenge to applied ethics. Journal of Philosophy of Education, 44, 237-273. general physical education teachers’ behaviors and beliefs associated with inclusion. 
Sport, Education, and Society, 9, 395-419.

405 Howe, P. D. (2009). Reflexive ethnography, impairment and the pub. Leisure Studies, 28, 489496.

407 International Federation of Adapted Physical Activity (IFAPA). (2004). By laws. Retrieved from http:/www.ifapa.biz/imgs/uploads/PDF/IFAPA\%20By-Laws.pdf

409 Jespersen, E., \& McNamee, M. (2008). Philosophy, adapted physical education and dis/ability. $410 \quad$ Sport, Ethics and Philosophy, 2, 87-96.

411 Kagan, J (2009). The three cultures: Natural sciences, social sciences, and the humanities in the $21^{\text {st }}$ century. Cambridge, NY: Cambridge University Press.

Klavina, A., \& Block, M. E. (2008). The effect of peer tutoring on interaction behaviours in inclusive physical education. Adapted Physical Activity Quarterly, 25, 132-158.

Leo, J., \& Goodwin, D. L. (2013). Pedagogical reflections on the use of disability simulations in higher education. Journal of Teaching in Physical Education, 32, 460-472.

Leo, J., \& Goodwin, D. (2014). Negotiated meanings of disability simulations in an adapted physical activity course: Learning from student reflections. Adapted Physical Activity Quarterly, 31, 144-161.

Lienert, C., Sherrill, C., \& Myers, B. (2001). Physical educators’ concerns about integrating children with disabilities: A cross-cultural comparison. Adapted Physical Activity Quarterly, 18, 1-17.

Macbeth, J. (2010). Reflecting on disability research in sport and leisure settings. Leisure Studies, 29, 477-485.

425 MacDonald, C. (2002). Relational professional autonomy. Cambridge Quarterly of Healthcare Ethics, 11, 282-289. 
427 Malloy, D. L., \& Zakus, D. (1995). Ethical decision making in sport administration. Journal of 428 Sport Management, 9, 36-85.

429 Morphy, L. Y., \& Goodwin, D. (2012). The experience of choice in physical activity contexts for adults with mobility impairments. Adapted Physical Activity Quarterly, 29, 132-150.

431 Nelson, H. L. (1995). Resistance and insubordination. Hypatia, 10, 23-40.

432 Oberle, K., \& Raffin Bouchal, S. (2009). Ethics in Canadian nursing practice: Navigating the journey. Toronto, ON: Prentice Hall.

434 Oliver, M. (1990). The politics of disablement. London: Macmillan Education.

435 Peers, D. (2012a). Interrogating disability: The (de)compositin of an recovering paralympian. 436 Qualitative Research In Sport, Exercise and Heath, 4, 175-189.

437 Peers, D. (2012b). Patients, athletes, freaks: Paralympism and the reproduction of disability. $438 \quad$ Journal of Sport and Social Issues, 36, 295-316.

439 Peers, D., Spencer-Cavaliere, N., \& Eales, L. (2014). Say what you mean: Rethinking disability language in Adapted Physical Activity Quarterly. Adapted Physical Activity Quarterly, 31, 265-282.

Pellegrino, E. D. (2000). Bioethics at century’s turn: Can normative ethics be retrieved? Journal of Medicine and Philosophy, 25, 655-675. doi: 0360-5310/2506-0655

444 Popke, E. J. (2003). Poststructuralist ethics: Subjectivity, responsibility and the space of community. Progress in Human Geography, 27, 298-316.

446 Prosser, J. (2000). The moral maze of image ethics. In H. Simons \& R. Usher, Situated ethics in educational research (pp. 116-132). New York, NY: Routledge.

448 Rossow Kimball, B., \& Goodwin, D. L. (2009). Self-determination and leisure experiences of 449 women living in two group homes. Adapted Physical Activity Quarterly, 26, 1-20. 
Seligman, M. (2012). Flourish: A visionary new understanding of happiness and well-being. New York, NY: Free Press.

Shakespeare, T. (2006). Disability rights and wrongs. London: Routledge.

Sherrill, C. (2004). Adapted physical activity, recreation, and sport: Crossdisciplinary and lifespan. New York, NY: McGraw-Hill.

Silva, C. F., \& Howe, P. D. (2012). Difference, adapted physical activity and human development: Potential contribution of capabilities approach. Adapted Physical Activity Quarterly, 29, 25-43.

Simons, H., \& Usher, R. (2000a). Situated ethics in educational research. New York, NY: Routledge.

Simons, H., \& Usher, R. (2000b). Introduction. In H. Simons \& R. Usher (Eds.), Situated ethics in educational research (pp. 1-11). New York, NY: Routledge.

Skrtic, T. (1995). Disability \& democracy: Reconstructing [special] education for postmodernity. New York, NY: Teachers College Press.

Standal, Ø. F. (2008). Celebrating the insecure practitioner. A critique of evidenced-based practice in adapted physical activity. Sport, Ethics and Philosophy, 2, 200-215.

Standal, Ø. F., \& Jespersen, E. (2008). Peers as resources for learning: a situated learning approach to adapted physical activity in rehabilitation. Adapted Physical Activity Quarterly, 25, 206-227.

Sullivan, M. (2005). Subjected bodies: Paraplegia, rehabilitation, and the politics of movement. In S. Termain (Ed.), Foucault and the government of disability (pp. 27-44). Ann Arbor, MI: University of Michigan Press.

Titchkosky, T. (2003). Disability, self, and society. Toronto, ON: University of Toronto Press. 
473

474

475

476

477

478

479

480

481

482

483

484

485
Titchkosky, T. (2011). The question of access: Disability, space, meaning. Toronto, ON: $\underline{\text { University of Toronto Press. }}$

Trussell, D. E. (2010). Gazing from the inside out during ethically heightened moments. Leisure Studies, 92, 377-395.

Updale, E. (2008). The ethics of the everyday: Problems professors are too posh to ponder. Clinical Ethics, 3, 34-36.

Usher, R. (2000). Deconstructive happening, ethical moment. In H. Simons \& R. Usher (Eds.), Situated ethics in educational research (pp. 162-185). New York, NY: Routledge.

van Manen, M. (1997). Research lived experience: Human science for an action sensitive pedagogy. London, ON: The Althouse Press.

Wadensten, B., \& Ahlstrom, G. (2009). Ethical values in personal assistance: Narratives of people with disabilities. Nursing Ethics, 16, 760-774.

Withers, A. J. (2012). Disability politics and theory. Halifax, NS: Fernwood Publishing. 


\section{$486 \quad$ Notes}

${ }^{1}$ Professional practice is defined as "a coherent, socially organized activity with notions of good practice within the practitioners’ understanding and skillful comportment. A practice has shared understandings about goals, skills and equipment and is continually being worked out in new contexts” (Benner, 1997, p. 50).

2 "Human science aims at explicating the meaning of human phenomena (such as in literary or historical studies of texts) and at understanding the lived structures of meanings (such as in phenomenological studies of the lifeworld)” (van Manen, 1997, p. 4).

${ }^{3}$ For this paper we have adopted the following understanding of ethics: Ethics relates to the values underpinning human conduct; the rightness and wrongness of actions and the goodness and badness of the motives and ends of actions. "A good is something we judge to be worthwhile to have, achieve, attend to, or participate in” (Higgins, 2010, p, 239).

${ }^{4}$ The dignified self is "a state of physical, emotional and spiritual comfort, with each individual valued for his or her uniqueness and his or her individuality is celebrated. Dignity is promoted when individuals are enabled to do the best within their capabilities, exercise control, make choices and feel involved in the decision-making that underpins their care” (Fenton \& Mitchell, 2002, p. 21).

\section{${ }^{5}$ For full detail on the suffix ive see The Oxford Shorter English Dictionary on historical principles, Oxford: Clarendon Press (1990 edition). Vol. 1, p. 1122}


${ }^{6}$ Nelson (1995) describes a (counter)story as a story in which the moral self-definition of the teller can be redefined by "undermining a dominant story, undoing it and retelling it in such a way as to invite new interpretations and conclusions” (p. 23). 